\title{
Chinese Name Authority Control in Asia: An Overview
}

\author{
Lily HU, Owen TAM, Patrick LO \\ Lingnan University Library, Hong Kong
}

\section{Introduction}

This research paper consists of 5 parts. Part I and II features the Chinese authority files created by the National Library of China, as well as the "Chinese Authority Database" set up jointly by the National Central Library and the National Taiwan University Library.

Part III is dedicated to the different authority control works and their latest developments implemented by the National Diet Library (Japan), "Toshokan Ryustu Centre", NACSISCAT operated by the National Institute of Informatics (Japan), and the MARC formats currently being used by the Waseda University Library (Tokyo).

Part IV focuses on the working relations between "China Academic Library \& Information System" and NACSIS-CAT.

Part V is devoted to the "JULAC-Hong Kong Chinese Authority, Name (HKCAN)" Database established by the academic libraries in Hong Kong since 1999.

\section{Mainland China}

\section{National Library of China}

(a) In order to enhance precision in bibliographic retrieval and to meet the demands raised by document indexing, the National Library of China has recently compiled and created the following ${ }^{1}$ :

(i) "Chinese Classification Subject Thesaurus" based on the "Chinese Library Classification";

(ii) “Chinese Subject Thesaurus";

(iii) "Subject Thesaurus to Classification Corresponding List";

(iv) “Chinese Classification Subject Thesaurus Database", collecting about 800,000 data and compiled 120,000 records of the database.

\footnotetext{
${ }^{1}$ SUN, Beixin. "The Development of Authority Database in national Library of China." Paper presented at Workshop on Authority Control among Chinese, Korean, and Japanese Languages (CJK Authority 3), Karuizawa, Tokyo, Kyoto, $24^{\text {th }}-28^{\text {th }}$ March 2002.
} 
(b) In order to provide standardization and format for authority control, the National Library of China also compiled the "Chinese MARC Authority Format" (trial edition) and "Description Rules for Entries of Authority Data" based on which to compile the authority databases.

(c) "Chinese Ancient Author Database" has collected Chinese ancient individual authors and group authors, whose works have been handed down for generations, from the ancient times to 1911 , containing more than 40,000 entries. In recent years, the National Library of China's Rare Book and Special Collection Departments have also compiled a total number of 11,000 records. Each record includes author's name, date of birth and death, dynasty, place of birth, style and assumed name, family relations, imperial examination's position, official position, major behaviour and representative works, etc.

(d) A "Modern Authority Database" was also set up by the National Library of China. It mainly collects authority records of authors who had expanded works and group author since 1912. The records include authors' name (original names, writing names), dates of birth and death, nationalities, titles of works, authors' genders, birth place, and position, etc. There are now more than 325,900 records in the Database, featuring mainly personal names, group names, and title names. About 40,000 records were compiled in year 2001.

\section{$\lambda$ Authority record example on author, "••" from National Library of China (CNMARC):}

\begin{tabular}{|c|c|c|}
\hline Control \# & 001 & A9400245 \\
\hline Fixed-length data & $\begin{array}{l}100 \\
152\end{array}$ & $\begin{array}{l}\text { \$a19940205achiy0120\#\#\#站 } \\
\text { \$aBDM }\end{array}$ \\
\hline $\begin{array}{l}\text { Heading } \\
\text { (Personal Name) }\end{array}$ & $200 \quad 0$ & $\begin{array}{l}\$ \mathrm{a} \cdot \bullet \$ \mathrm{c}(\cdot, \text { \$f1920 1996) } \\
\$ 7 \mathrm{ba} \$ \text { abai yang }\end{array}$ \\
\hline General Public note & $300 \quad 0$ & 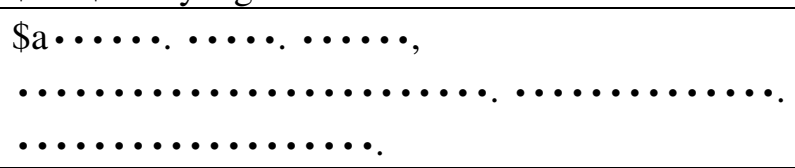 \\
\hline See From & $\begin{array}{ll}400 & 0 \\
400 & 0 \\
\end{array}$ & $\begin{array}{l}\$ 0 \cdots \ldots \ldots \ldots, \cdots \cdots: \$ 6 a 05 \$ a \cdot \cdots \\
\$ 6 a 05 \$ 7 \text { ba } \$ \text { ayang cheng fang }\end{array}$ \\
\hline Cat. Source & $801 \quad 0$ & \$6CN\$b・.\$c19940205 \\
\hline Source Data found & 810 & $\$ a \cdot \ldots$ \\
\hline
\end{tabular}

Note:

$\lambda \quad$ MARC21 versus CNMARC format comparison documented in (APPENDIX I). 
$\lambda \quad$ Overall statistical data on Chinese Authority File by (National Library of China) is documented in (APPENDIX II).

$\lambda$ Authority record example on "William Shakespeare" in CNMARC format (supplied by Peking University Library) is documented in (APPENDIX III).

\section{Taiwan}

In 1990, the National Central Library (NCL) and the National Taiwan University (NTU) Library jointly established a Chinese authority taskforce for tackling Chinese authority control works in Taiwan.

(a) Initial Setup - in June 1996, after having collected a total number of 180,000 personal name authority records, and 10,000 group name records from NCL, plus another 30,000 personal names from NTU, the Authority Taskforce then began combining all the collected records into a single authority file. This authority file was later pronounced as the "Chinese Name Authority Database" (CNAD). The NCL records are created on the Chinese authority MARC (CMARC) format set out by Chinese libraries in Taiwan, whereas the NTU files use MARC21 format for their authority data. ${ }^{2}$ Once the database consolidation is completed, the new authority file will be made available on NBINet, with data searching and downloading functionalities provided via remote login. Such setup would allow libraries around the world to share and make maximum use of this helpful cataloguing reference tool in the most convenient and speedily fashion.

(b) Size of Existing Database - while CNAD's consolidation work still continues, the current Database contains slightly more than 420,000 authority records, featuring mainly personal names, plus a small number of group/corporate names.

(c) Record Format/Standards - in order to ensure consistency of authority data, as well as retrieval precision, only one unique entry is created for each individual author. Authority records are built upon the CMARC originated in Taiwan, with other guidelines and principles set out by the CNAD Workgroup.

(d) Capabilities of Software System - the initial setup of the Database Software

2 "NCL and NTU to Jointly Establish Database of Chinese Authority Files" National Central Library Newsletter, Vol. 30, No. 4, February, 1999, pp. 1. 
was completed in May 2001, and was officially entitled as, "Chinese Name Authority Database Workgroup (Taiwan)" accordingly. The CNAD Software is now equipped with the basic capabilities, such as, data searching/data retrieval, record maintenance, and downloading, etc. The CNAD Software also provides different internal codes and MARC formats for users to choose from during record display and downloading. Trial use is also available for other collaborating or participating libraries. They may simply apply to NCL and seek permission for accessing the CNAD Database.

(e) User Manual - in April 2002, both the "CNAD User Manual", and the "CNAD Software Maintenance Manual" were also made available in electronic format for the participating libraries' references.

(f) Record example on author, " $\infty$ " from CNAD:

\begin{tabular}{|c|c|c|}
\hline Control \# & 001 & 31834 \\
\hline Fixed-length data & $\begin{array}{l}100 \\
152\end{array}$ & $\begin{array}{l}\text { \$a19950621achiy09 ea } \\
\text { \$aCCR }\end{array}$ \\
\hline $\begin{array}{l}\text { Heading } \\
\text { (Personal Name) }\end{array}$ & 2001 & $\$ a \cdot \$ b \cdot \$ f 1866-1945 ?$ \\
\hline See From & $\begin{array}{ll}400 & 0 \\
400 & 0 \\
400 & 0 \\
400 & 0 \\
400 & 0 \\
400 & 0 \\
400 & 1 \\
400 & 1 \\
400 & 1 \\
400 & 1\end{array}$ & 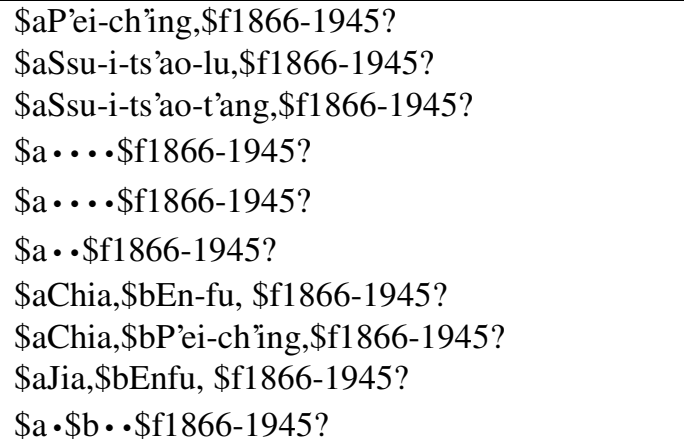 \\
\hline Cat. Source & 8010 & \$acw\$b・• \$c199506 \\
\hline Source Data found & $\begin{array}{l}810 \\
810 \\
810\end{array}$ & $\begin{array}{l}\$ \mathrm{a} \cdot \cdots \cdots \cdot \cdots \cdot \cdot \cdot \cdot 82: \$ \mathrm{~b} \cdot 718 \\
\$ \mathrm{a} \cdot \cdots \cdot \cdots \cdot \cdot \cdot \cdot \cdot 58 \\
\$ \text { aHis Tsao-Ch'ang hsien chih, } 1987: \$ \text { bcaption } \\
(\text { Chia En-fu) }\end{array}$ \\
\hline ier & 830 & \\
\hline
\end{tabular}

\section{Japan}

Currently, there are 3 different types of MARC formats being used throughout different libraries and research institutes in Japan, and they are as follows:

$\lambda \quad$ JAPAN/MARC - provided by the National Diet Library (Japan) 
$\lambda \quad$ TRC/MARC - based on enhanced JAPAN/MARC format, and is provided by "Toshokan Ryustu Centre", a commercial company in Japan. TRC/MARC is used mainly by public libraries.

$\lambda$ NACSIS-CAT (National Centre for Science Information Systems Cataloguing System) - a Japanese bibliographic utility developed by the National Institute of Informatics (Japan) and its data is used widely and mainly by academic libraries in Japan.

\section{Further Descriptions on Different MARC Formats Used in Japan:}

\section{(a) JAPAN/MARC (A)}

The existing JAPAN/MARC Authority File (JAPAN/MARC (A)) was created and maintained by the National Diet Library (Japan), with coverage restricted to name headings only. For exchange of records, the UNIMARC format is used. The current JAPAN/MARC (A) is available for sale in magnetic tape from Japan Library Association or in CD-ROM format from Kinokuniya Co. Ltd. The latest version of CD-ROM is year 2000 edition. The actual use of statistics on NDL's JAPAN/MARC (A) is unknown.

\section{Record example in existing JAPAN/MARC (A) format from NDL} (will be replaced by UNIMARC in 2003):

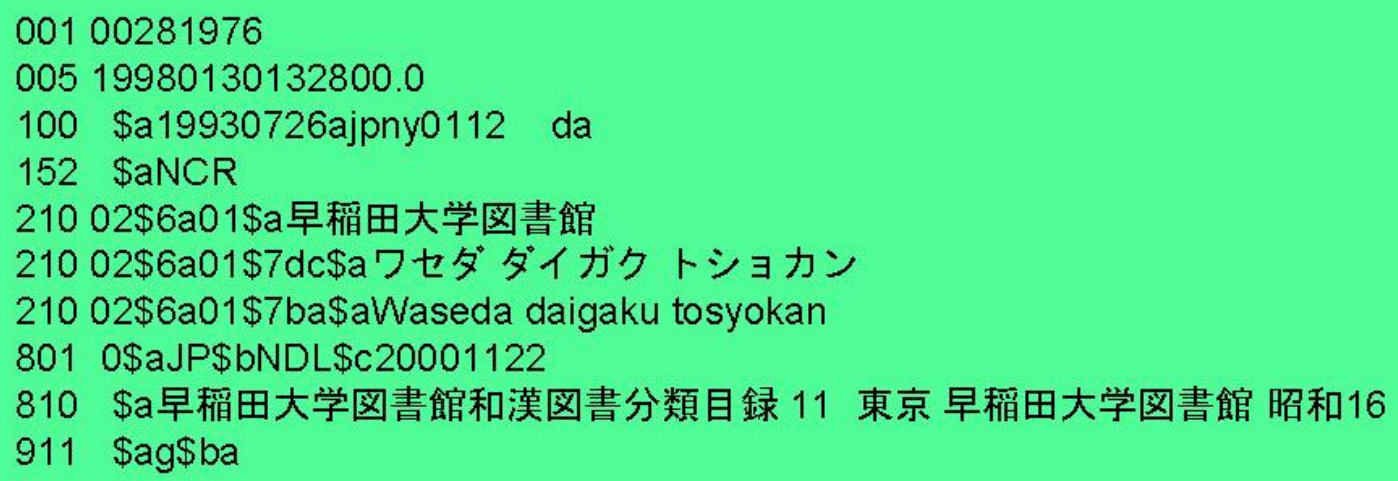

\section{(b) TRC/MARC}

According to the TRC corporate profile, TRC/MARC has been adopted by $70 \%$ of Japanese Libraries, and (NACSIS-CAT also stores TRC/MARC in their referral database). The TRC Name Authority File is updated on a daily basis. The file is available in FTP, magnetic tape, and CD-ROM format, and is delivered to the customers on a weekly basis. In addition to the TRC Name Authority file, TRC also 
uses a different type of MARC format, TRC/MARC, which is supposed to be an enhanced version of the original JAPAN/MARC format.

Authority record example from TRC/MARC:

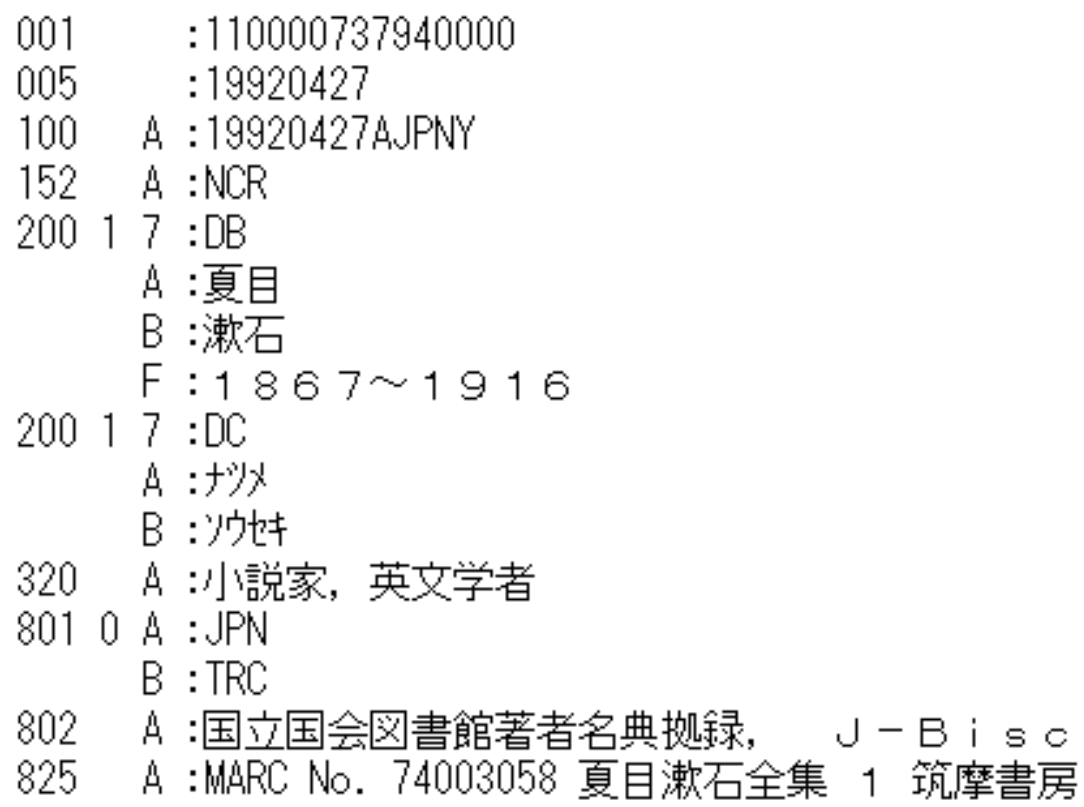

\section{(c) NACSIS-CAT}

NACSIS-CAT is the online cataloging system, which National Institute of Informatics (Japan) provides. ${ }^{3}$ The main purpose of the NACSIS-CAT is to construct a union catalogue of books and serials covering the whole country through cooperative data entry (shared cataloging) from the participating university libraries. This union database, complemented with useful authority data, prevents duplicate cataloguing work in libraries and facilitates labour saving and quicker processing. NACSIS-CAT can be accessed on the World Wide Web through the Webcat service.

\section{(c.1) Unique Characteristics of NACSIS-CAT \& Its Authority Data}

$v$ To be free from the restrictions posed by MARC structure, NACSIS-CAT provides both bibliographic and authority data in non-MARC format (RAW data only). Member libraries may simply download or extract data from NACSIS-CAT and manipulate it according to their own in-house cataloguing practices afterwards.

\footnotetext{
3 NII (Japan) is a government-funded institute, and was founded in April 2000 as an Inter-University Research Institute, to implement comprehensive research in the field of Information science. This involves the reorganization of NACSIS (National Centre for Science Information Systems) and assumption of its functions.
} 
$v$ Once becoming a member, authority data will be free of charge for downloading from NACSIS-CAT. However, in order to be compatible with the NACSIS-CAT, participating institutes must first install the CAT-P (their own communication protocol) client software for cataloguing. Furthermore, NII also provides various in-house and overseas training programmes or workshops for participating libraries on the specialized and latest developments on NASIS-CAT's operations.

$v$ Coverage - NACSIS-CAT includes author' $\mathrm{s}$ name and uniform title authority files. In addition to Japanese and Western name headings, NACSIS-CAT also includes a large number of name headings of Chinese authors. Recently, they have also begun to introduce Korean headings with original script into this union database.

\section{Example on NACSIS-CAT's name authority in non-MARC format:}

\section{$\langle$ ¿A00151899>}

HDNG:夏目，漱石(1867-1916)川ナツメ、ソウセキ

LCAID:DA00151899

TYPE:p

PLACE:牛込(東京)

DATE: $1867-1916$

SF:夏目，金之助川ナツメ，キンノスケ

SF:*Natsume, SIseki, 1867-1916

SF:Natsume, Sôseki

SF:Natume, Sôseki

SF:Natsume, Kinnosuke, 1867-1916

SF:H aryme, Coçkr

SF:Sôseki

SF:NItsImah, SIsahkI

NOTE:文化人名録による。

NOTE:EDSRC:夏目漱石；寺田宙彦；鈴木三重吉；内田百間(筑摩書房, 1968)

NOTE:EDSRC:La porte : roman/Sôseki; traduit du japonais par Corinne Atlan(Philippe Picquier, c1992) NOTE:夏目濑石集(河出書房新社，1965.8)

NOTE:切抜帖より/夏目漱石著(春陽堂, 1926.1)

\section{(c.2) NACSIS-CAT - Services on International Scale}

In order to raise the standard of science research, and to promote the distribution of science information on a global scale, NII is developing a number of international projects and co-operations to improve access to information process by overseas universities and research institutes. Currently, 31 universities and research institutes in Europe and Asia participate in NII's Cataloging Systems project and provide access to the NACSIS-CAT services. These include major research libraries, which have collections of Japanese language materials, such as the British Library, and 
other institutes devoted to the researches on Japan and East Asia. They have registered more than 270,000 books and serials (August 2002). In addition, the "Science Information Exchange Project with China" was initiated in 1998. NII has been assisting computerization of the catalogue records of the Beijing Center for Japanese Studies with the assistance of the Japan Foundation. For a full list of participants of NACIS-CAT, please see (Appendix IV).

(c.3) Overall Statistics and Participating Institutes:

More than $95 \%$ of Japanese colleges/universities are currently using NACSIS-CAT. As of March 1999, a total number of 670 libraries had connected online to NACSIS-CAT for the sharing of bibliographic and authority data. And in September 2002, the total number of institutions using NACSIS-CAT reached 995.

Overall statistics on NASIS-CAT participating institutes
follows ${ }^{4}$ :
\begin{tabular}{|l|c|}
\hline \multicolumn{1}{|c|}{ Member Libraries/Types } & Number \\
\hline National Universities & 97 \\
\hline Local Public Universities & 73 \\
\hline Private Universities & 461 \\
\hline Inter-University Research Institutes & 14 \\
\hline Junior Colleges and Colleges of Technology & 176 \\
\hline Others & 174 \\
\hline Total & $\mathbf{9 9 5}$ \\
\hline
\end{tabular}

\footnotetext{
${ }^{4}$ National Institute of Informatics (Japan) Homepage - Statistics. Available from: http://www.nii.ac.jp/CAT$\underline{\text { ILL/INFO/sanka-kikan.html }}$
} 


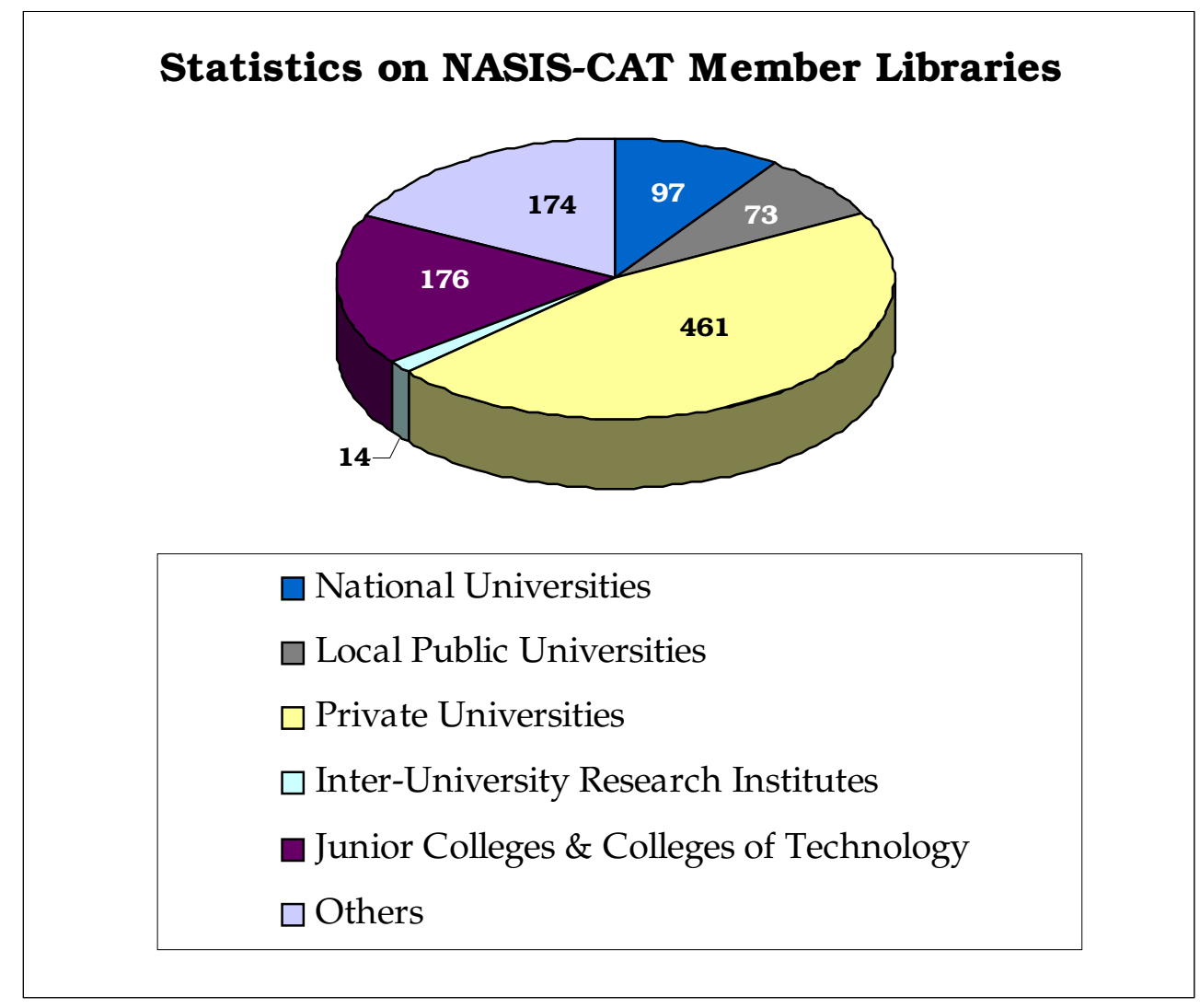

\section{(d) CJK Authority Control at Waseda University Library (Tokyo) -}

Currently, 2 different types of authority record are being used at Waseda University Library (Tokyo).

In order to support data retrieval in original Japanese script, Waseda University Library has created their own unique authority record structure by executing the concept of repeating regular tags for non-roman data, as suggested in MARBI Discussion Paper, No. 111. In fact, they are currently using triple 1xxs to represent different forms of Japanese data in both their bibliographic and authority records, e.g.:

$\lambda \quad 1^{\text {st }} 1 \mathrm{xx}-$ Vernacular

$\lambda \quad 2^{\text {nd }} 1 \mathrm{xx}-$ Katakana transliteration

$\lambda \quad 3^{\text {rd }} 1 \mathrm{xx}-$ Japanese Romanization (Hepburn)

Meanwhile, Waseda University Library also subscribes to OCLC authority services for headings in romanized/Western-language form. For CJK authors, in order to facilitate easy identification, original Japanese script is introduced to tag 667 for cataloguers' references. 
Currently, Waseda University Library is trying to merge these 2 different types of authority format into a single one, with the aim of facilitating comprehensive and concurrent retrieval of bibliographic records by the same author under one single search.

\section{Examples of Chinese Authority Records provided by Waseda University Library:}

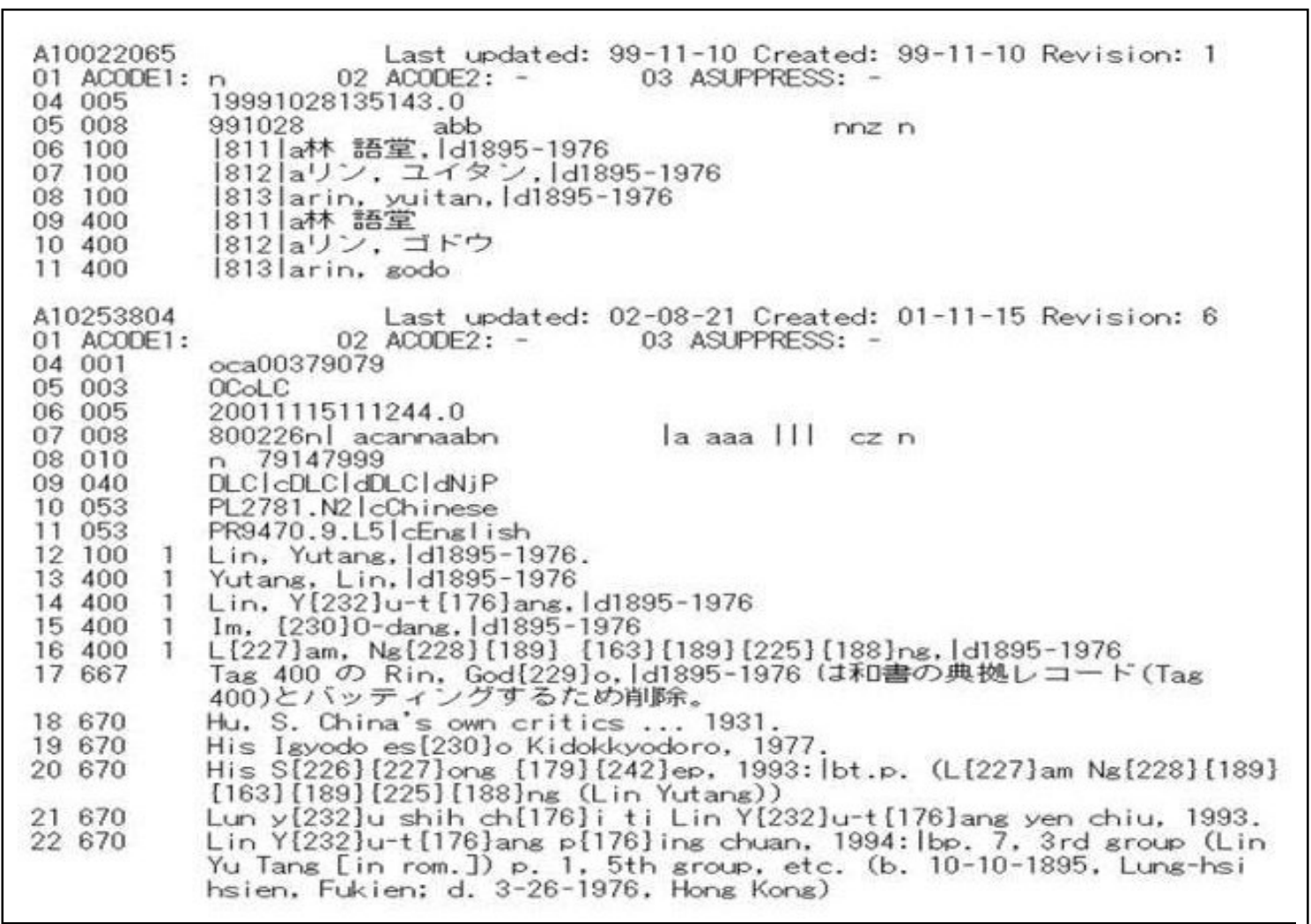

\section{CALIS \& NACSIS-CAT}

\section{Relations between CALIS \& NACSIS-CAT}

$\lambda$ Networked environment has greatly enhanced resources sharing and cataloguing works between different libraries of various regions. CALIS (China Academic Library \& Information System) now has more than 100 members subscribing to its various services. Within CALIS, there are a total number of 14 member institutions in China taking part in this joint cataloguing project on Japanese language materials.

$\lambda$ Each of these individual 14 member libraries can also gain direct access to NII (Japan)'s NACSIS-CAT independently, as they are also required to contribute their own cataloguing data to NACSIS-CAT in return via the use of CAT-P Protocol.

$\lambda$ Currently, there are more than 22,000 bibliographic records in Japanese language being held inside CALIS. More than $90 \%$ of these Japanese bibliographic records are 
originated from NACSIS-CAT. Japanese language records are downloaded from NACSIS-CAT at no cost once becoming a member. The Peking University Library is one of the 14 members of CALIS participating in this joint cataloguing project, and did not become a member until October 2000.

$\lambda$ Until now, CALIS has only bibliographic records, and does not come with an authority database. However, the Japanese authority data is maintained while the corresponding bibliographic record is being downloaded - in order to facilitate CALIS in building its own authority database to complement the existing bibliographic data.

\section{$\lambda$ Other Information:}

(a) Although NACSIS-CAT contains cataloguing data in many different languages, Peking University Library currently downloads only Japanese language data from NACSIS-CAT, while relying on other databases for the cataloguing of foreign language materials.

(b) NII also provides training workshops for their NACSIS-CAT members at no cost. However, at Peking University Library, Japanese data cannot be uploaded directly onto their database, as it needs to go through a MARC conversion programme. Hence, NII's training workshops are not applicable in this case.

(c) CALIS and NACSIS-CAT - flowcharts on the overall working flow, MARC format conversion is documented in (APPENDIX V).

\section{Hong Kong}

In June 1998, Lingnan University Library (Hong Kong) organized jointly with the Department of Library and Information Science, Zhongshan University (China), the "Joint Symposium on Library \& Information Services" in commemoration of the University' s $30^{\text {th }}$ Anniversary. The Symposium attracted over 200 scholars, librarians and library vendors from Mainland China, Taiwan, Singapore, North America and local institutions, etc.

At the Symposium, there was a consensus that a regional network should be formed to enable cooperation and resources sharing among the 4 Chinese speaking areas, i.e., Mainland China, Taiwan, Hong Kong and Macau. It was proposed that a Chinese Resource Sharing Workgroup (consisted of 9 different member libraries from 4 regions) be formed 
to coordinate the developments of the cooperative projects. Three cooperative projects were then proposed for consideration:

- Chinese Name Authority Database

- Multimedia Database on Dr. Sun Yat-sen

- Union Catalogue of Chinese Rare Books

HKCAN Project ${ }^{5}$-- In January 1999, a group of academic libraries in Hong Kong agreed

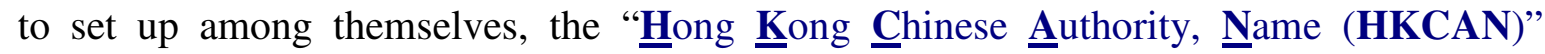
Workgroup for establishing an authority database that would reflect the unique characteristics of the Chinese authors and organizational names. $^{6}$

This project was spearheaded by both Lingnan and Chinese University Libraries of Hong Kong, aiming to build a Chinese name authority database with CJK scripts, with the goal modeled after the Programme for Cooperative Cataloguing, to improve and streamline authority-control operations, in order to make them "Better", "Faster", and "Cheaper" while producing "More". ${ }^{7}$ At the $2^{\text {nd }}$ HKCAN Meeting in May 1999, it was agreed that Lingnan University Library would serve as Convenor of the HKCAN Workgroup, while the Chinese University of Hong Kong Library would take up the responsibility of hosting the Databases itself.

\section{JULAC-HKCAN Project Homepage (http://hkcan.In.edu.hk)}

\footnotetext{
5 The acronym of "HKCAN" is purposely designed to encourage each of the Workgroup participants that 'Hong Kong can!"

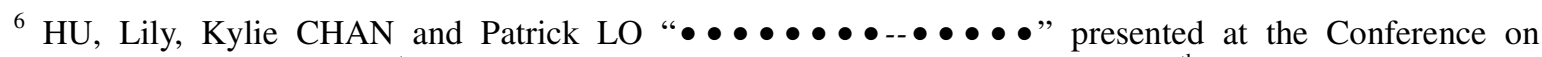
Chinese Libraries in the $21^{\text {st }}$ Century" at the Chinese University of Hong Kong on $4^{\text {th }}$ November 1999.

${ }^{7}$ HU, Lily, Kylie CHAN and Patrick LO “A Collaborative Project on Chinese Name Authority Control : the HKCAN Model", Journal of East Asian Libraries, no. 120, February, 2000. Articles also presented at Council on East Asian Librarian (CEAL) Annual Meeting in San Diego in March 2000.
} 


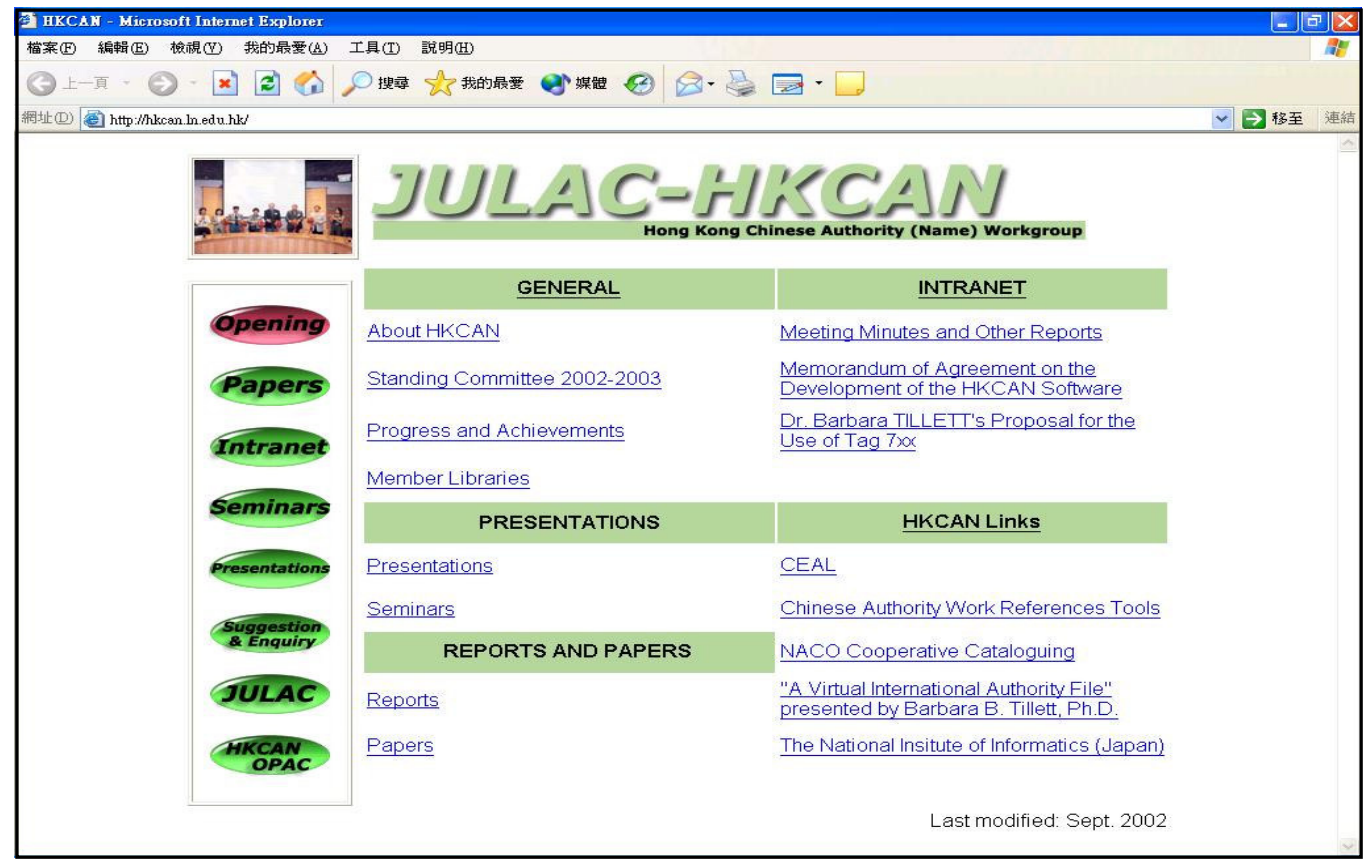

The establishment of the HKCAN Project was carried out in the following 3 parts/stages:

$\lambda \quad$ Design of HKCAN Authority Record Model

$\lambda$ Indexing and Display of Authority Records in OPAC and its Linkage with Bibliographic Database.

$\lambda$ Setup of HKCAN Database: development and maintenance of software and hardware

After 4 years of intensive hard work, the HKCAN Workgroup finally completed the initial phase of database building, and its success has attracted international attention and recognition. The Project finally became a JULAC (Joint University Libraries Advisory Committee $^{8}$ Project in year 2001, and was officially renamed as JULAC-HKCAN Database in the same year. The JULAC-HKCAN Database now contains over 100,000 authority records with original Chinese scripts, and the number of records is increasing at about a 1,000 a month. On $4^{\text {th }}$ October, 2002, a 1-day Opening Seminar was launched at the Host Institution, (Chinese University of Hong Kong Library) to celebrate this special occasion, with internationally acclaimed guest speakers from the United States, including representatives from the Library of Congress (US), RLG, and MARBI Multilingual Taskforce to give presentations.

\section{Note:}

$\lambda$ Overall statistical data on JULAC-HKCAN versus Chinese Authority File by (National Library of

\footnotetext{
${ }^{8}$ The Joint University Librarians Advisory Committee (JULAC) was first established in 1967 by the Heads of University Committee (HUCOM). It is a forum to discuss, coordinate, and collaborate on library information resources and services among the libraries of the eight tertiary education institutions funded by the University Grants Committee (UGC) of the Hong Kong SAR Government.
} 
China) is documented in (APPENDIX II).

$\lambda$ HKCAN (MARC21) vs CNMARC - format comparison documented in (APPENDIX I).

\section{(a) Design of HKCAN Authority Record Model}

(a.1) Hong Kong is a bilingual society, with both Chinese and English as the official languages. Many local authors publish in English, in addition to their first language, Chinese. Therefore, the biggest challenge for the Workgroup laid in identifying a solution that would support the comprehensive retrieval of bilingual publications under the same authors in a concurrent fashion under our OPAC system.

(a.2) After 2 years of planning and with valuable advices from various Chinese authority control experts, the existing 7xx Authority model was agreed upon with the recommendation from the Library of Congress (U.S.) in May 2000.

(a.3) 7xx Authority Record Example of author, "..." is as follow:

\begin{tabular}{|c|c|c|}
\hline Ctrl. \# Identifier & 003 & HkCAN \\
\hline Date \& Time - Latest Transaction & 005 & 19990127162938.0 \\
\hline Fixed-length Data & 008 & 801020nl acannaab la aaa \\
\hline LC Ctrl. \# & 010 & \$an 50062079 \\
\hline System Ctrl. \# & 035 & $\$ a($ OCoLC\#)oca00096472 \\
\hline Cata. Source & 040 & \$aDLC\$cDLC\$dDLC\$dDLC-R\$dHKIEd\$dHkCAN \\
\hline Character Sets & 066 & $\$ c \$ 1$ \\
\hline Heading--Personal Name & $100 \quad 1$ & \$aLiu, James J. Y \\
\hline \multirow{3}{*}{ See From } & $400 \quad 1$ & \$aLiu, Jo-yü \\
\hline & $400 \quad 1$ & \$aRyu, Jakugu \\
\hline & $400 \quad 1$ & \$aYu, Yag-u \\
\hline \multirow{4}{*}{ Source Data Found } & 670 & \$aHis Elizabethan and Yuan ... 1955 \\
\hline & 670 & $\begin{array}{l}\text { \$aHis Yu yen yu shih, c1988:\$bt.p. (James J.Y. Liu) } \\
\text { pref., etc. (b. 1924; d. May 1986; was pro. of Chinese } \\
\text { and chairman of the Dept. of Asian Languages at } \\
\text { Stanford Univ.) }\end{array}$ \\
\hline & 670 & $\begin{array}{l}\text { \$aHis Chungguk sihak, 1984:\$bp. } 5 \text { (James J.Y. Liu : } \\
\text { Yu Yag-u) }\end{array}$ \\
\hline & 670 & \$a•....., 1987:\$bt.p. (••) \\
\hline Historical data & 678 & $\$ a b .1926$ \\
\hline Heading Linking Entry & $700 \quad 1$ & $\$ \mathbf{a} \boldsymbol{\infty}$ \\
\hline
\end{tabular}

(a.4) In early 1999, representatives of Lingnan University Library visited various libraries in Mainland China, as well as Taiwan, with the aim of learning more about the overall operations of Chinese authority control works being implemented in these two places. Meanwhile, several Chinese cataloguing experts from the National Library of China and Peking University Library were invited to come to Hong Kong by Lingnan University Library to conduct several small-scale workgroups and 
seminars on Chinese authority works - to share with the Hong Kong cataloguers their on valuable experiences and expertise.

(a.5) In year 2001, HKCAN member libraries were busy with Pinyin conversion. As soon as the Pinyin conversion project was completed, member libraries began to contribute their records to the Database starting from January, 2002.

(a.6) Database Consolidation -- the de-duplication and merging of 150,000 contributed records was completed in July 2002. At the moment, the database has about 120,000 records, mainly personal names, all with Chinese script provided in $7 \mathrm{xx}$ field.

(a.7) In year 2000, representatives of HKCAN first presented the HKCAN project at the CEAL (Council on East Asian Libraries) Annual conference and received overwhelming responses. In the past year, trial accesses were granted to the National Library of Africa, National Library of Australia, East Asian Library of Columbia University (NYC), Waseda University Library (Tokyo) and some other local libraries.

(a.8) In order to facilitate the sharing and exchanges of information and resources among the library communities in Asia, the HKCAN Workgroup also initiated the following programmes to strengthen their liaison:

(i) Comprehensive Coverage - in addition to fulfilling the special cataloguing needs of the bilingual community in Hong Kong, the Database also aims at providing a more comprehensive coverage of Chinese names in the Asian Pacific Region. In October 1999, the HKCAN Workgroup, also acquired the authority file in CD-ROM from National Library of China (Beijing), which will be introduced to the HKCAN Database at a later stage. In November 1999, a memorandum of agreement was signed between the representatives of the National Central Library (Taipei) and the HKCAN Workgroup, to the effect that the NCL (Taipei) would share and exchange with HKCAN Workgroup its enhanced authority control software as well as its authority data in the future.

(ii) Liaison/Networking with Overseas Libraries - close to the end of Database consolidation, trial accesses were granted to the following overseas libraries since 1999, e.g.: 
$\lambda \quad$ East Asian Library of Columbia University (NYC)

$\lambda \quad$ National Library of Australia

$\lambda \quad$ Waseda University Library (Tokyo)

(iii) External Assistance for Database Consolidation - in year 2001, HKCAN Workgroup invited 2 Chinese cataloguing librarians from Peking University Library to come to Hong Kong to assist in the database consolidations for a total number of 5 months.

\section{(b) Indexing \& Display of Authority Records in OPAC \& its Linkage with Bibliographic Database}

(b.1) While setting up the authority database, the Workgroup also worked closely with the library system vendor, Innovative Interfaces Inc. to find a software solution to support the $7 \mathrm{xx}$ authority model, and fortunately, all the existing contributing HKCAN Members happen to employ the same library system.

(b.2) In August 2001, a remote 7xx Beta-Test site was installed by III for Members' testing on its actual functionality. The linkages of 1xx English/romanized headings and 7xx CJK heading greatly enhanced the OPAC searching. The progress is encouraging, and the new software to support 7xx will be in operation in mid 2003. In 2002, 2 of the existing HKCAN members installed 7XX Beta-Test software on their own library systems for further testing. ${ }^{9}$

\section{Example on 7XX Beta-Test Screenshot}

\footnotetext{
${ }^{9}$ Lingnan University Library \& The Hong Kong Polytechnic University Pao Yue-kong Library
} 


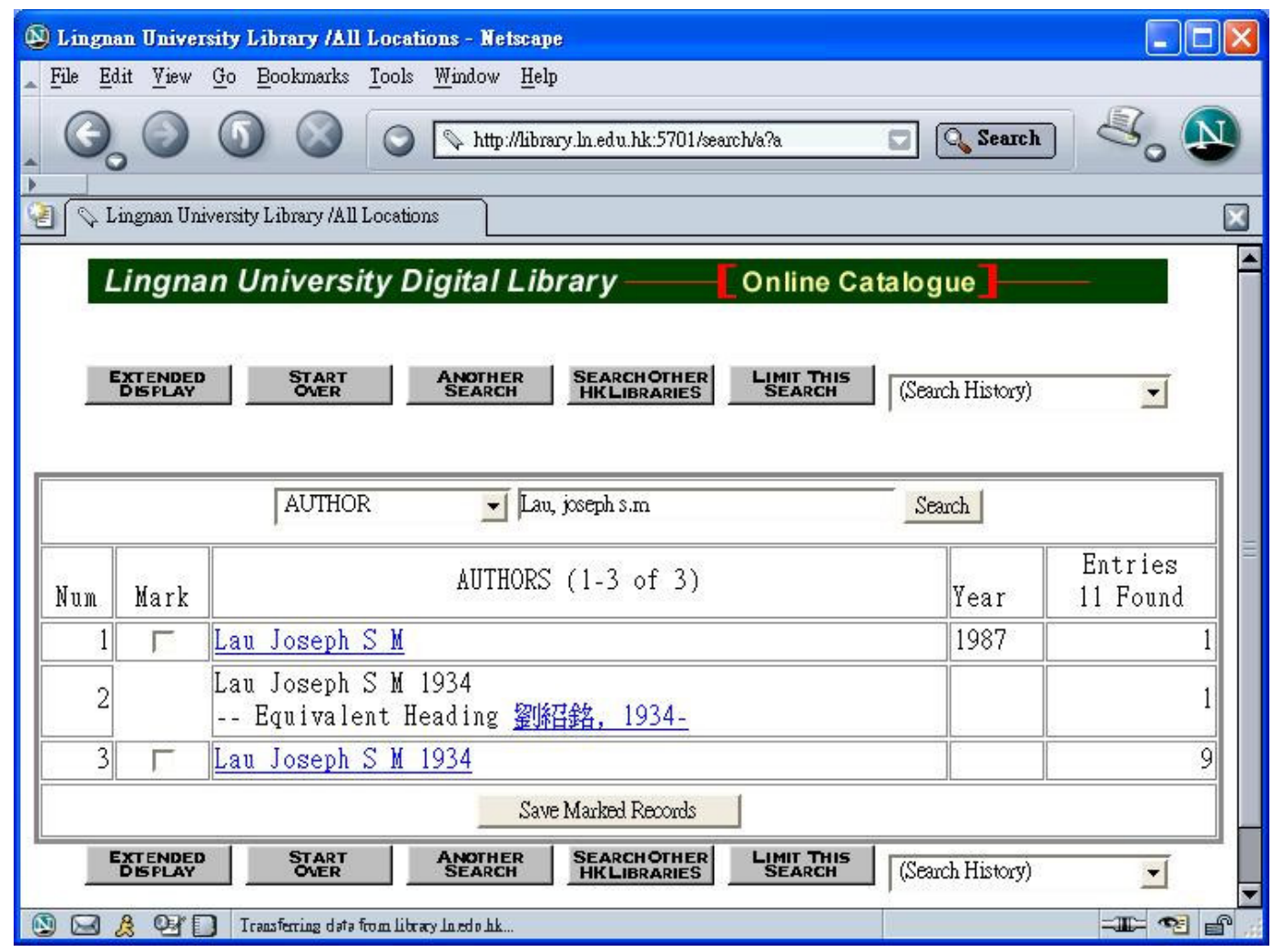

*Note: Special feature of 7xx authority enhancement - allowing concurrent and comprehensive bibliographic retrieval of bilingual publications by the same author under a single search in WebPAC. For example, to search for author, "Lau, Joseph" in English form, the system will also prompt all equivalent headings in original Chinese script.

\section{(c) Setup of HKCAN Database: Development \& Maintenance of Software \& Hardware}

At the end of 1999, a software vendor in Taiwan, "Transmission Information System Co., Ltd." (TISC) was contracted to upgrade the NCL's authority control software for the HKCAN Database. (The future development and on-going maintenance of HKCAN Software was taken over by"

"/TTS Co., Ltd. since August 2002)

\section{HKCAN Database User Interface Screenshot}




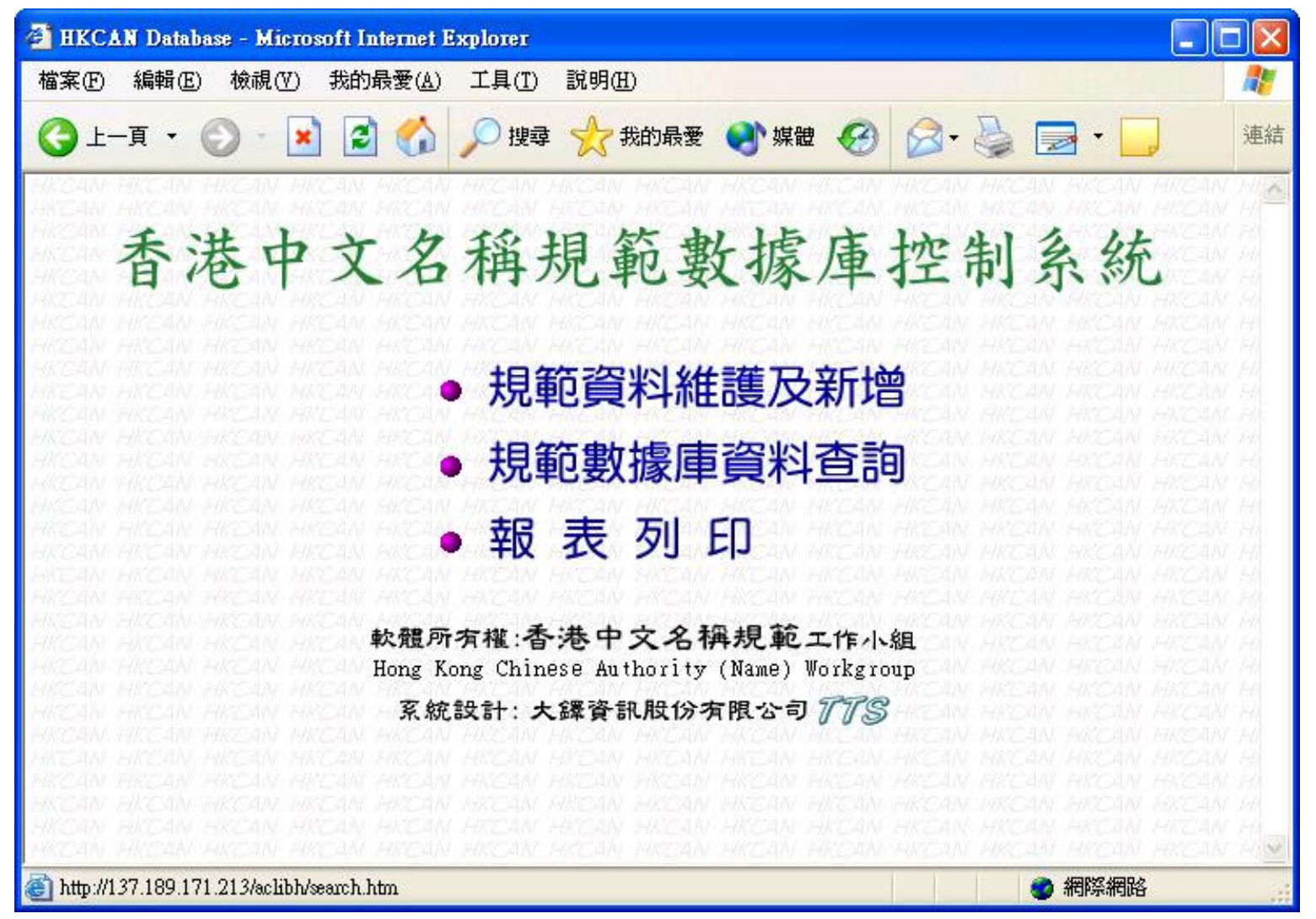

(d) HKCAN Database's Current Status

(d.1) Presently, the HKCAN Project's staffing and operational costs are shared among the 6 participating libraries.

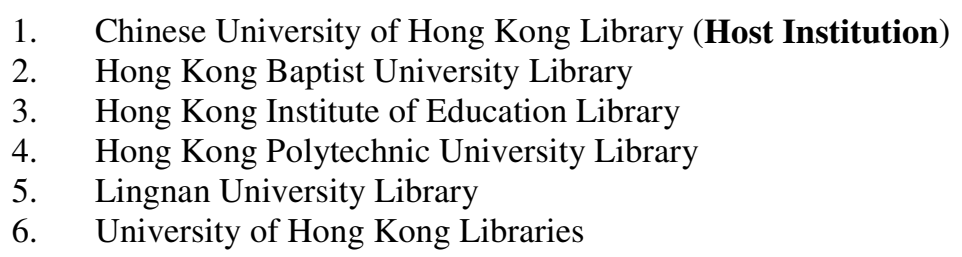

(d.2) In addition to cost sharing, the above academic libraries also contributed a large amount of authority records to the HKCAN Database. As an observer, the City University of Hong Kong Library also contributed more than 60,000 authority records along to the HKCAN Database in January 2001.

(d.3) In addition, there are also a number of local, as well as overseas libraries that have already expressed interest in using the HKCAN Database, e.g.:

\section{Hong Kong:}

1. Hong Kong Academy of Performing Arts Library

2. Hong Kong Central Library

3. Hong Kong Hospital Authority Library

4. Hong Kong Legislative Council Library

5. Hong Kong Monetary Authority Library

6. The Open University of Hong Kong Library 


\section{Mainland China, Taiwan and Macau:}

1. Biblioteca Central de Macau

2. National Library of China

3. Peking University Library

\section{Overseas:}

1. East Asian Library, Columbia University (NYC)

2. Library of Congress

3. Macquarie University Library

4. University of New South Wales Library

5. Waseda University Library

(d.4) Size of Database -- based on recent statistics, the HKCAN Database has collected more than 142,000 authority records from 7 local JULAC libraries. During the Database consolidation, over 8,400 records have been updated/amended. More than 15,600 records have been removed during the duplication removal. Upon the completion of the duplication removal, the Database now holds more than 100,000 unique records, including:

$\lambda \quad 73,000$ personal names

$\lambda \quad 14,000$ entries for group name

$\lambda \quad 1,000$ conference/meeting names

$\lambda \quad 17,000$ uniform titles

(d.5) Official Opening -- After 4 years of intensive hard work, a 1-day Joint University Librarians Advisory Committee-HKCAN Opening and Seminar was launched at the Host Institution (The Chinese University of Hong Kong Library) in October 2002 to celebrate the meaningful collaboration and the fruition among the academic libraries.

\section{CONCLUSION}

No one can deny that authority control work is an indispensable part of the daily cataloguing routine. However, when it comes to the treatment of non-Roman/non-Western authority data, many libraries are still using merely Romanized form. And the JULACHKCAN model has been developed specifically to tackle this problem. JULAC-HKCAN not only made original Chinese scripts available in their authority records in MARC21 format, they also managed to identify a software solution, which enabled the concurrent and yet comprehensive retrieval of bilingual publications by the same author under a single search. Such practice has already proven to be successful and has attracted international attentions, and some overseas libraries have already expressed their interests in participating in this project. 
Hong Kong has always carried a harmonious blend of things both ancient and modern, and of Western influences and ethnic Chinese traditions, creating an irresistible mix of cultures and heritages. As an international city, and as the Special Administrative Region of China, Hong Kong has a special role to play. Not only it is the living fusion of East and West, Hong Kong also lives to promote the East-West cultural and resources exchanges, as well as understanding, it also serves as a gateway to the immeasurable resources in China, and JULAC-HKCAN is one of the very best examples.

With mission modeled closely after the city of Hong Kong, the HKCAN Database is set out to infuse authentic Asian contents and perspectives into the readily available and yet widely accepted data and format introduced from the West -- and through members' active participation, the HKCAN Database can look forward to better cooperative cataloguing and resources sharing of oriental Asian materials among all libraries on a global scale.

\section{References}

HU, Lily, Kylie CHAN and Patrick LO “...........” presented at the Conference on Chinese Libraries in the $21^{\text {st }}$ Century" at the Chinese University of Hong Kong on $4^{\text {th }}$ November 1999.

HU, Lily, Kylie CHAN and Patrick LO “A Collaborative Project on Chinese Name

Authority Control : the HKCAN Model", Journal of East Asian Libraries, no. 120, February, 2000. Articles also presented at Council on East Asian Librarian (CEAL) Annual Meeting in San Diego in March 2000.

"NCL and NTU to Jointly Establish Database of Chinese Authority Files" National Central Library Newsletter, Vol. 30, No. 4, February, 1999, pp. 1.

SUN, Beixin. "The Development of Authority Database in national Library of China." Paper presented at Workshop on Authority Control among Chinese, Korean, and Japanese Languages (CJK Authority 3), Karuizawa, Tokyo, Kyoto, $24^{\text {th }}-28^{\text {th }}$ March 2002.

National Institute of Informatics (Japan) Homepage - Statistics. Available from: 


\section{Notes}

The authors take this opportunity to thank Peking University Library and Waseda University Library (Tokyo) for providing the Chinese and Japanese authority record examples as well as other information on authority control works.

\section{Special thanks are due to the following library colleagues for their immeasurable support and contribution to this research paper}

Ms. Kazuko Matsui (National Diet Library)

Mr. Haruo Asoshina (National Institute of Informatics)

Mr. Yoshiaki Taikoh (TRC)

Mr. Masayuki Shoji, Mr. Rikuo Takagi, and Ms. Mitsuko Kanazawa (Waseda University Library (Tokyo)

Ms. LIU Lijing and Ms. PAN Yun (Peking University Library) 
(APPENDIX I)

\begin{tabular}{|c|c|c|c|c|c|c|c|c|c|}
\hline \multirow[b]{2}{*}{ Ctrl. \# } & \multicolumn{3}{|r|}{ MARC21 used by (HKCAN) } & \multicolumn{3}{|r|}{ CNMARC used by (National Library of China) } & \multicolumn{3}{|r|}{ CMARC used by CNAD } \\
\hline & 001 & & 000042412 & 001 & & A9400245 & 001 & & 31834 \\
\hline Ctrl. \# Identifier & 003 & & HkCAN & & & & & & \\
\hline $\begin{array}{l}\text { Date \& Time - } \\
\text { Latest Transaction }\end{array}$ & 005 & & 20001027121223.0 & & & & & & \\
\hline \multirow{2}{*}{ Fixed-length Data } & \multirow{2}{*}{008} & & \multirow{2}{*}{ 810810nc acannaabn la aaa III } & 100 & & $\$ a 19940205$ achiy0120 ea & 100 & & $\$$ \$19950621achiy09 ea \\
\hline & & & & 152 & & $\$ a B D M$ & 152 & & $\$ a C C R$ \\
\hline LC Ctrl. \# & 010 & & $\$$ an 81047202 & & & & & & \\
\hline System Ctrl. \# & 035 & & $\$ a(D L C \#) n$ 81047202a & & & & & & \\
\hline Cata. Source & 040 & & \$aDLC\$beng\$cDLC\$dOCoLC\$dHkCU\$dHkCAN & 801 & 0 & $\$ 6 \mathrm{CN} \$ \mathrm{~b} \bullet \bullet \$ \mathrm{c} 19940205$ & 801 & 0 & $\$ a c w \$ b \cdot \$ c 199506$ \\
\hline Character Sets & 066 & & $\$ c \$ 1$ & & & & & & \\
\hline \multirow{2}{*}{$\begin{array}{l}\text { Heading--Personal } \\
\text { Name }\end{array}$} & \multirow{2}{*}{100} & \multirow{2}{*}{1} & \multirow{2}{*}{ \$aBai, Xianyong,\$d1937- } & 200 & 0 & $\$ \mathrm{a} \bullet \bullet \$ \mathrm{c}(\bullet, \$ \mathrm{f} 1920 \sim 1996)$ & \multirow{2}{*}{200} & \multirow{2}{*}{1} & \multirow{2}{*}{$\$ \mathrm{a} \cdot \$ \mathrm{~b} \cdot . \$ \mathrm{f} 1866-1945 ?$} \\
\hline & & & & 200 & 0 & \$7ba\$abai yang & & & \\
\hline Public General Note & & & & 300 & 0 & 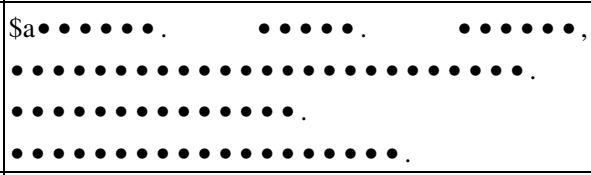 & & & \\
\hline \multirow{4}{*}{ See From } & \multirow{4}{*}{400} & \multirow{4}{*}{1} & \multirow{4}{*}{ \$wnne\$aPai, Hsien-yung,\$d1937- } & \multirow{2}{*}{400} & \multirow[b]{2}{*}{0} & \multirow{2}{*}{$\$ 0 \bullet \bullet \bullet \bullet \bullet \bullet \bullet, \bullet \bullet \bullet \bullet: \$ 6 \mathrm{a} 05 \$ \mathrm{a} \bullet \bullet \bullet$} & 400 & 1 & \$aP’ei-ch’ing,\$f1866-1945? \\
\hline & & & & & & & 400 & 1 & \$aSsu-i-ts'ao-lu,\$f1866-1945? \\
\hline & & & & \multirow{2}{*}{400} & \multirow{2}{*}{0} & \multirow{2}{*}{$\$ 6 \mathrm{a} 05 \$ 7 \mathrm{ba} \$$ ayang cheng fang } & 400 & 1 & \$aSsu-i-ts'ao-t’ang,\$f1866-1945? \\
\hline & & & & & & & 400 & 1 & $\$ a \cdot \ldots$ \$f1866-1945? \\
\hline \multirow{3}{*}{ Source Data Found } & 670 & & \$aAuthor' Sse hsien chi $(\bullet \bullet \bullet\}, 1967$. & \multirow{3}{*}{810} & \multirow{3}{*}{\multicolumn{2}{|c|}{$\$ \mathrm{a} \bullet \bullet \bullet$}} & 810 & & $\$ \mathrm{a} \cdot \ldots \ldots \ldots, \cdot, \cdot 82: \$ \mathrm{~b} \cdot 718$ \\
\hline & \multirow{2}{*}{670} & & \multirow{2}{*}{$\$ a \bullet \bullet \bullet \bullet \bullet,[1995]: \$ b t . p .(\bullet \bullet \bullet)$} & & & & 810 & & $\$ a \cdots \cdot \cdots \cdot \cdot \cdot \cdot 58$ \\
\hline & & & & & & & 810 & & $\begin{array}{l}\text { \$aHis Tsao-Ch'ang hsien chih, } 1987 \text { : \$bcaption (Chia } \\
\text { En-fu) }\end{array}$ \\
\hline $\begin{array}{l}\text { Heading Linking } \\
\text { Entry }\end{array}$ & 700 & 1 & $\$ \mathrm{a} \bullet \bullet \bullet, \$ \mathrm{~d} 1937-$ & & & & & & \\
\hline $\begin{array}{l}\text { General } \\
\text { Cataloguer's Note }\end{array}$ & & & & & & & 830 & & $\$ a \cdots, \cdots ; \cdots, \cdots, \cdots$ \\
\hline
\end{tabular}


(APPENDIX II)

\section{Overall Statistics}

\section{HKCAN vs Chinese Authority File by (National Library of China)}
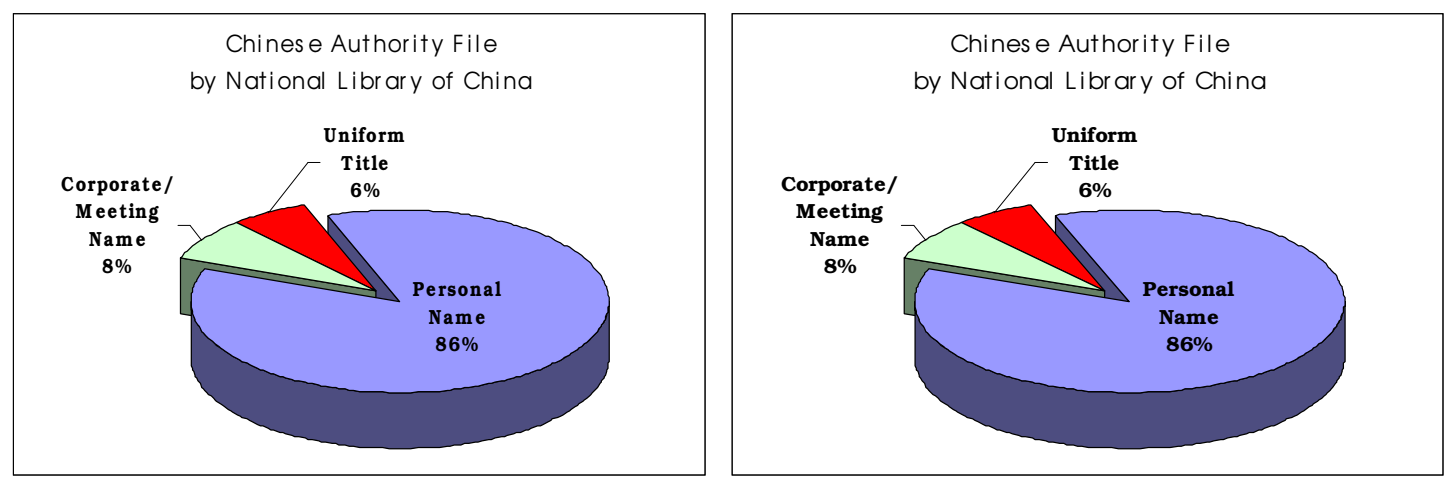

\begin{tabular}{|l|c|c|c|c|}
\hline \multirow{2}{*}{ Authority Database/File } & \multicolumn{2}{|c|}{ HKCAN } & \multicolumn{2}{c|}{$\begin{array}{c}\text { Chinese Authority File } \\
\text { by } \\
\text { (National Library of China) }\end{array}$} \\
\hline Personal Name & 73,372 & $69 \%$ & 285,000 & $86 \%$ \\
\hline Group/Meeting Name & 14,449 & $14 \%$ & 25,000 & $8 \%$ \\
\hline Uniform Title & 17,667 & $17 \%$ & 20,000 & $6 \%$ \\
\hline Total & 105,488 & $100 \%$ & 330,000 & $100 \%$ \\
\hline
\end{tabular}




\section{(APPENDIX III)}

Authority record example on Shakespeare William in CNMARC

\begin{tabular}{|c|c|c|}
\hline 200 & 1 & 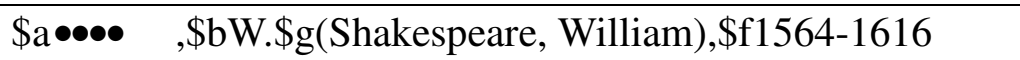 \\
\hline 200 & 1 & \$7ec\$aSha Shi Bi Ya\$g(Shakespeare, William),\$f1564-1616 \\
\hline 700 & 1 & \$aShakespeare,\$bWilliam,\$f1564-1616 \\
\hline 801 & 0 & \$aCN\$bPUL\$c19940307 \\
\hline 810 & & $\$ a E B(V .15$ p. 248$)$ \\
\hline 810 & & $\$ a C H(1989 ;$ p.1552) \\
\hline 830 & & 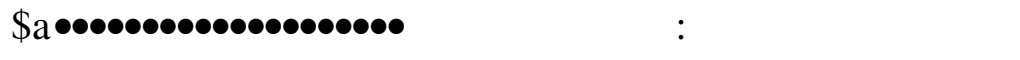 \\
\hline & & 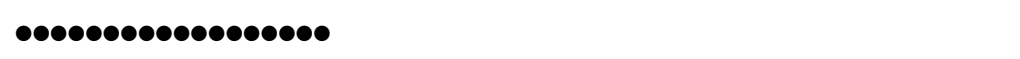 \\
\hline
\end{tabular}




\section{(APPENDIX IV)}

\section{Participating Institutes of NACIS-CAT}

(1) Beijing Center for Japanese Studies

(2) Bodleian Library, University of Oxford

(3) Cambridge University Library

(4) China Agricultural University Library

(5) Dalian University of Technology Library / ( .......)

(6) Dept. of Japanese Artiquities, The British Museum

(7) Dept. of Japanese Studies, University of Heidelberg

(8) East Asian Institute, Japan Center, University of Munchen

(9) East Asian Library, University of Zurich

(10) East-Asien Library, Katholieke Universiteit Leuven

(11) Geophysical Institute, University of Alaska

(12) Institute of East Asian Studies, Duisburg University

(13) Institute of Japanese Studies, Hallym Academy of Sciences, Hallym University

(14) Japan Center Library, University of Marburg

(15) Japan Cultural Center, Bangkok, The Japan Foundation

(16) Japan Cultural Center, Koln, The Japan Foundation

(17) Japanese-German Center Berlin

(18) Ji Lin University Library / ( $\ldots \ldots$...)

(19) Nanjing University Library / ( . . . . )

(20) Oriental and India Office Collections, The British Library

(21) Peking University Library / ( . . . . )

(22) School of East Asian Studies Library, University of Sheffield

(23) School of Oriental and African Studies, University of London

(24) Scottish Centre for Japanese Studies, University of Stirling

(25) Society for Buddhist Understanding, Germany

(26) Sun Yat-Sen University Libraries / ( . . . . . )

(27) Teachers College, Columbia University Japan

(28) The Asia library, Stockholm University

(29) The Japan Foundation London Language Centre

(30) Tianjin Library / ( . . . )

(31) Wuhan University / (.....)

\section{The following libraries will participate in NACSIS-CAT soon:}

Centre for Documentation and Information, Chinese Academy of Social Sciences / (..........)

(33) Dalian University of Foreign Languages $/(\ldots \ldots \ldots \ldots \ldots)$

(34) East China Normal University Library / $(\ldots \ldots \ldots \ldots)$

(35) Fudan University Library / (......)

(36) JETRO London Center

(37) LiaoNing Provincial Library / $(\cdots \cdots)$

(38) Northeastern University Library / ( . . . . )

(39) Shanghai Jiaotong University / ( . . . . . )

(40) The Library of Renmin University of China / ( . . . . . )

(41) Tsinghua University Library / $(\ldots \ldots)$

(42) Xiamen University Library / ( .....) 


\section{(APPENDIX V)}

\section{Flow Chart ${ }^{10}$}

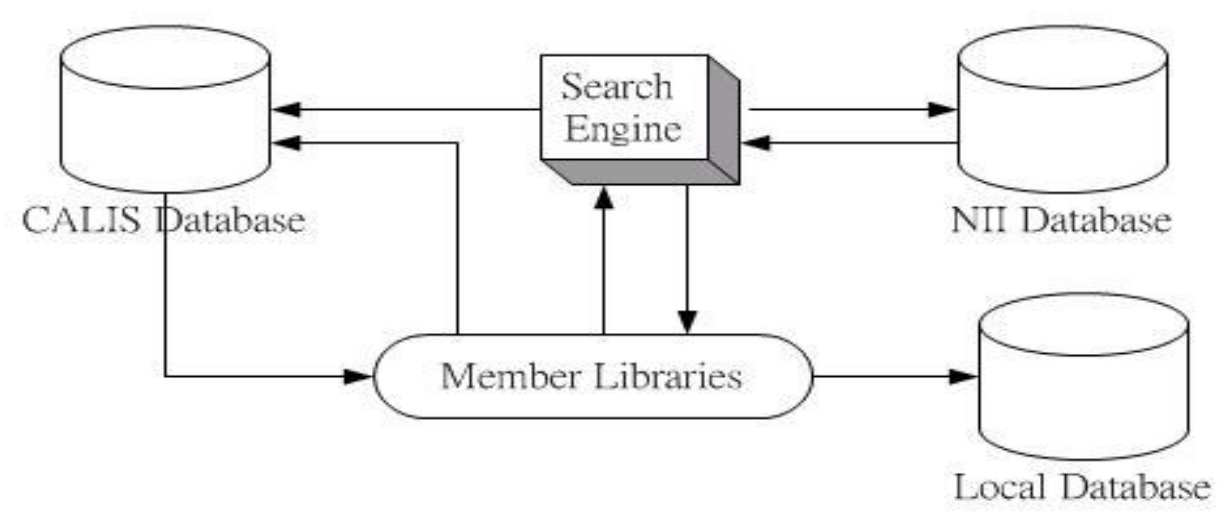

\section{Overall Workflow}

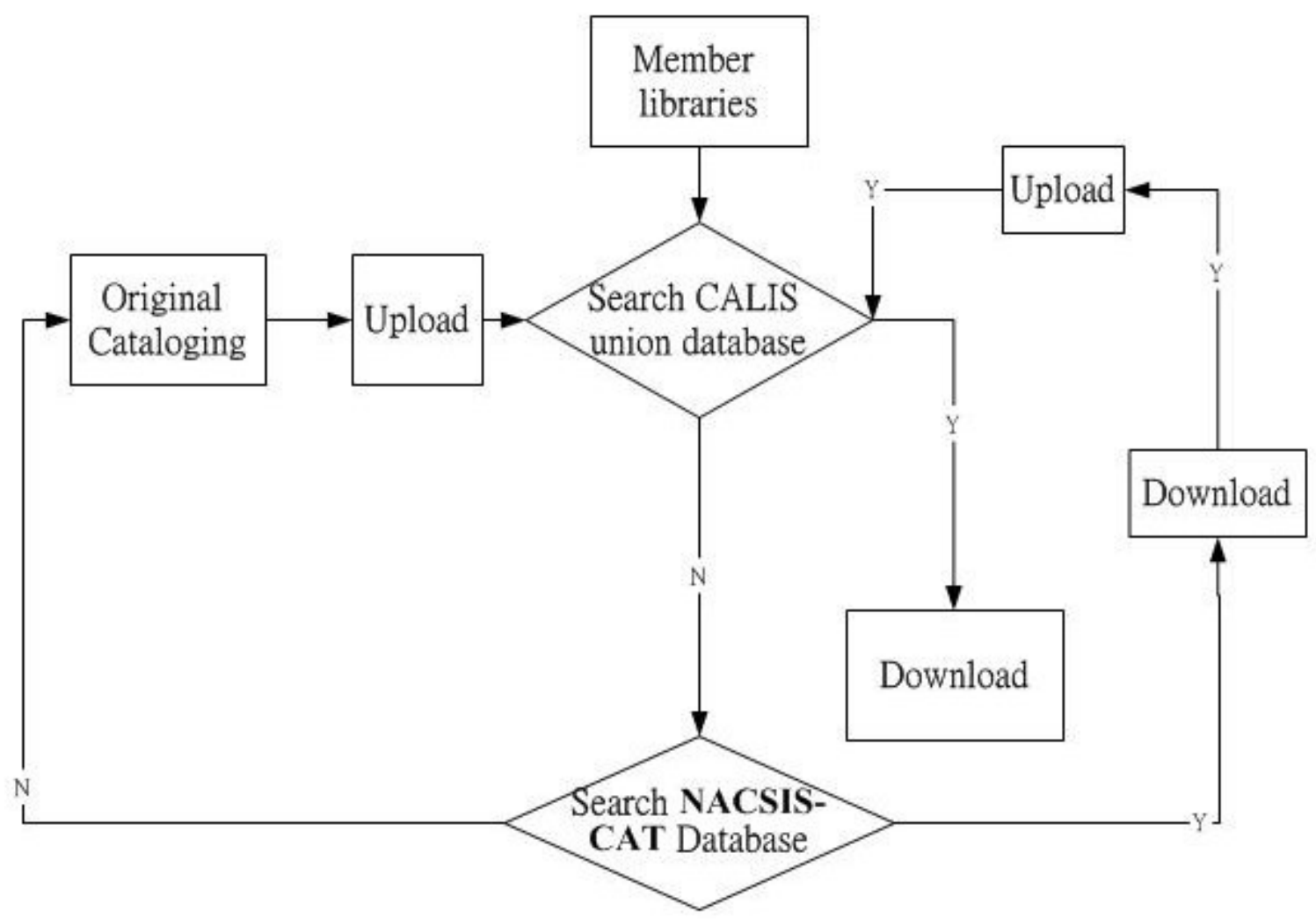

${ }^{10}$ This flowchart documents in details how member libraries contribute and download data from NACSIS-CAT via CALIS, including steps for MARC and data conversion. 